\title{
Microsystem enabled single cell monoclonal antibody cloning for antibody immunotherapy of HIV infection (features)
}

\author{
Qing Song* \\ Department of Chemical and Biomolecular Engineering, New York University Tandon School of Engineering, USA
}

Monoclonal antibodies (mAbs) have well established their valuable roles as therapeutic proteins. Second generation of mAbs as therapeutical products for immunotherapy of HIV infection has made significant progress in recent studies. A recent small phase 1 clinical trial has demonstrated that monoclonal antibodies could be safe and effective in reducing HIV-1 viraemia in human. This study also suggested that passive transfer of $\mathrm{mAbs}$ will provide a potential alternative strategy for HIV-1 prevention, therapy, and cure. Single cell $\mathrm{mAb}$ cloning using either hydridoma technique or fluorescent activated cell sorting (FACS) is less efficient. Microsystem will enable a more efficient approach for single cell MAb cloning of bNAbs for HIV infection.

\section{Production of monoclonal antibodies (mAbs)}

Monoclonal antibodies (mAbs) are highly desirable as therapeutic proteins, and also widely defined as the most significant class of biologics for use as pharmaceuticals and diagnostics due to their specificity of binding, homogeneity, ability to be produced in unlimited quantities and predictable safety [1]. Since the first therapeutic $\mathrm{mAb}$ was commercialized in 1986, product approvals and sales of mAbs have grown significantly. Forty seven mAbs have been approved and marketed in the United States and Europe as of November 10, 2014 [2-5]. Advancement of understanding of diseases at a molecular level drives the rapid antibody product development. Techniques including genomics, proteomics and systems biology continue to provide important new targets for modulating disease. MAbs often provide the most rapid route to a clinical proof of concept for activating, inhibiting, or blocking these new targets, and therefore are often the first product candidates advancing to clinical trials. Increasing and aging worldwide population and the increasing standard of living in emerging markets also fuel the growth in mAbs sales and global market expansion of the pharmaceutical market [6]. More than $200 \mathrm{mAbs}$ are in clinical trial and over $300 \mathrm{mAb}$ candidates are currently in development. In 2015 , the sales revenue of therapeutic antibodies is $\$ 80$ billion and is predicated to reach $\$ 150$ billion in 2020 .

The classic method of $\mathrm{mAb}$ production is the hybridoma technique [7-10] (Figure 1). Antibody-secreting B lymphocytes (B cells) are isolated from animals immunized with an antigen. Isolated B cells are immortalized by chemically-induced fusing with a tumor cell line (a myeloma). The fused cells are called hybridomas and can be maintained in vitro. Standard techniques could generate $10^{3}-10^{4}$ clones in each experiment. A substantial amount of work is needed to identify those cells that produce antibodies with a defined specificity. Traditional methods to screen for specific clones within these populations have relied on depositing cells into 96- or 384-well microtiter plates at densities of approximately one cell per well. After 7-14 days, the supernatants from these cultures are then assessed for the antibody secretions. Positive wells are selected for single cell cloning expansion. Limiting-dilution method for single-cell selection needs the hundreds to thousands of ELISA tests. Overall efficiency of this method is very low both practically and economically. All of the antibodies produced by descendants of one hybridoma cell are identical. Antibodies that are produced by hybridomas are known as monoclonal antibodies.

Advancement of technologies for speeding up the process

There have been several attempts to speed up the production of mAbs. ClonePixFL technology from Genetix Ltd plates out cells in

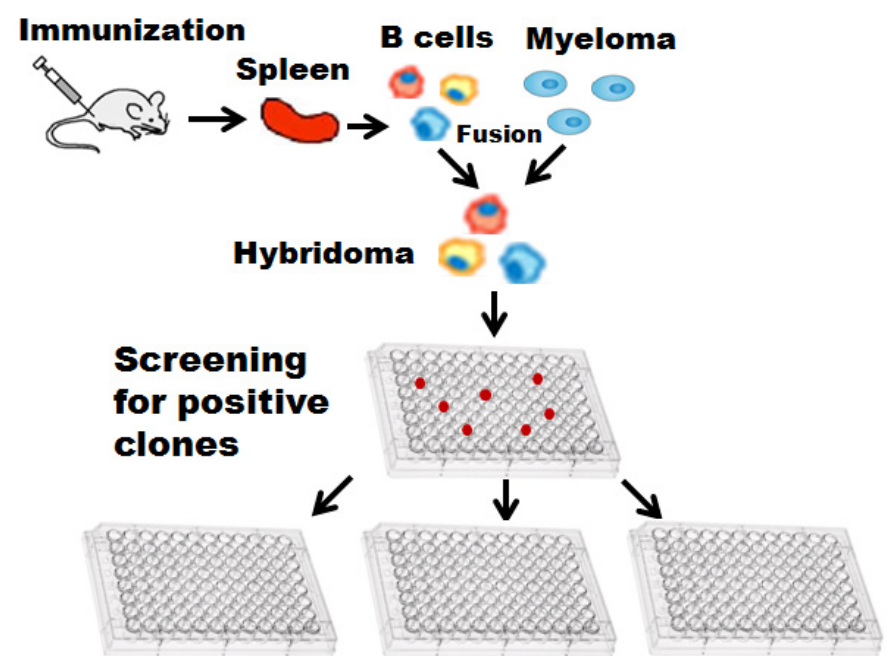

Single Cell Hybridoma Cloning by Limit Dilution

Figure 1. Hybridoma technique. Isolated parimary B cells fused with myeloma to form hybridoma. Positive antibody secreting hybridoma will be screening extensively by limi dilution.

Correspondence to: Qing Song, Department of Chemical and Biomolecular Engineering, New York University Tandon School of Engineering, 6 Metrotechcenter, Brooklyn, NY 11201, USA, Tel: 646997-3863; E-mail: qs299@nyu.edu

Received: January 10, 2016; Accepted: February 12, 2016; Published: February 16,2016 
semisolid medium, allow cells to grow 5-14 days into colonies. The secreted protein of interest is trapped in the vicinity of the colony and illuminated by a fluorescently-labeled antibody present in excess in the medium that diffuses freely through the medium until it recognizes and complexes with the secreted protein. The amount of fluorescence accumulating around a colony is proportional to the amount of target protein secreted by the colony. The positive clones can be selected and picked up based on quantitative protein secretion or specific protein production [11,12]. Integration of novel clone selection algorithms developed by Invitrogen and ClonePix technique allows for rapid screening through thousands of clones in a few hours.

Fluorescent activated cell sorting (FACS) technique sorts single cells based on the expression patterns of specific cell surface markers $[13,14]$. This approach has been applied extensively to select antigen-specific B cells using antigen coated magnetic beads [15], fluorochrome-labeled antigens via multi-parameter FACS [16-19]. The major advantage of FACS technology in this application is that cells to be sorted can be clearly distinguished in terms of their stage of development and differentiation based upon the expression patterns of specific cell surface markers. In general, B cells at any stage can be sorted, but class-switched memory B cells and antibody-secreting cells (ASCs, i.e. plasmablasts and plasma cells) are of special interest to obtain relevant $\mathrm{mAbs}$ as they bear somatically mutated $\mathrm{B}$ cell antigen receptors (BCRs) with high affinities. Whereas for FACS, the correlation is not straightforward between cells that stain positive and those that actually secrete the antibodies. Both methods have improved the efficiency of screening by serial dilution.

\section{Antibody (Ab) immunotherapy of HIV infection}

MAbs have been successfully used as immunotherapy products for cancer [20] and autoimmune disease [21,22]. Passive transfer of first generation broad neutralization antibodies (bNAbs) including b12, 2G12, 2F5 or $4 \mathrm{E} 10$ has been proved to protect against simian immunodeficiency viruses (SIVs) that express the HIV-1 envelope glycoproteins infection in macaques [23-29]. Clinical studies have discovered many human antibodies that can neutralize multiple strains of HIV [30-35]. Antibodies have been proved to be effective in suppressing HIV-1 infection in humanized mice [36], rhesus monkeys [37], and macaques [38]. A recent small phase 1 clinical trial [39] included 29 volunteers (17 HIV-infected and 12 uninfected) demonstrated that a single infusion of an experimental antibody $3 \mathrm{BNC17}$ significantly reduced HIV levels in infected people for as long as 28 days. For the first time, this study established that passive infusion of single bNAbs can have profound effects on HIV-1 viraemia in humans and can be used as immunotherapy products.

\section{Significance of single cell monoclonal antibody (mab) cloning}

Elicitation of potent broadly neutralizing antibodies (bnAbs) against HIV viruses is one of the key attributes of humoral immune response to HIV vaccines. Antibody responses to vaccination have been mainly measured as overall serum binding or functional titer such as neutralization to the HIV viruses. While serum antibody titers provide a general humoral response to potential HIV vaccines, polyclonal antibodies are of little value for defining the critical components of the host humoral response to HIV vaccines. Profiling monoclonal antibodies (mAbs) generated from vaccinated animal models or clinical samples will reveal crucial aspects of the immunological response to potential HIV vaccines. Generated mAbs can be further characterized for their binding affinity, neutralization, and crossreactivity. These details will provide valuable information for HIV vaccine designs. These mAbs can also be used as Ab immunotherapy for HIV infection. Hybridoma and EBV immortalized B cell lines have been used to generate human monoclonal antibodies. But their overall transformation efficiencies are extremely low (about 1-3\%) [40-45]. Development of single cell $\mathrm{mAb}$ cloning techniques will be crucial for generating potential Ab immunotherapy for HIV infection.

\section{Single cell monoclonal antibody (mab) cloning using FACS}

Single cell Ab cloning techniques were originally developed to study mechanisms that control tolerance in the B cell compartment [46]. Wardemann and coworkers have found that a portion of newly generated B cells in the human bone marrow expressed self- and polyreactive antibodies and their development was regulated at two independent self-tolerance checkpoints [46]. The techniques were modified to identify B cells which secrete broad neutralization Abs [47-50] or screen single B cells expressing Abs that bind to the HIV-1 envelope spike $[51,52]$. The single cell $\mathrm{Ab}$ cloning techniques successfully cloned many naturally arising, broad and potent HIV1-neutralizing antibodies (bNAbs) that were up to 2 to 3 orders of magnitude more potent than those previously discovered [47-67]. The single cell $\mathrm{Ab}$ cloning techniques have also been used to isolate $\mathrm{mAbs}$ from other animal models such as rhesus macaque [69,70].

As illustrated in Figure 2, single memory B cells were isolated using fluorescence activated cell sorting (FACS) based on surface expressed markers such as gp140 [52], or a modified gp120 core [53,54], gp41 [68], gp $160 \Delta c^{\mathrm{BaL}}$ [55] or a combination of a serial markers including CD3, CD27 and CD19 etc [54]. Some studies also used engineered protein probes to identify and sort epitope-specific B cells $[66,67]$. Immunoglobulin (Ig) genes of isolated single B cells were amplified using single cell reverse transcription and polymerize chain reaction (RT-PCR). Amplified heavy- and light-chain antibody regions were cloned into eukaryotic expression vectors and transfected into human embryonic kidney (HEK) 293 or 293 T cells to produce monoclonal human antibodies of the same specificity in vitro. Recombinant antibodies were purified from supernatants and tested for antigen reactivity at the end using ELISA.

Single cells sorted using FACS were based on surface markers which can distinguish their development stages and differentiation status. Ig-cloning step is time-consuming and prevents high-throughputs analysis of the B cell repertoires [68]. The single cell sorting using FACS is based on the surface markers not antigen specificity. Antigenic specificity was tested at the end of procedure. Single cell isolation was

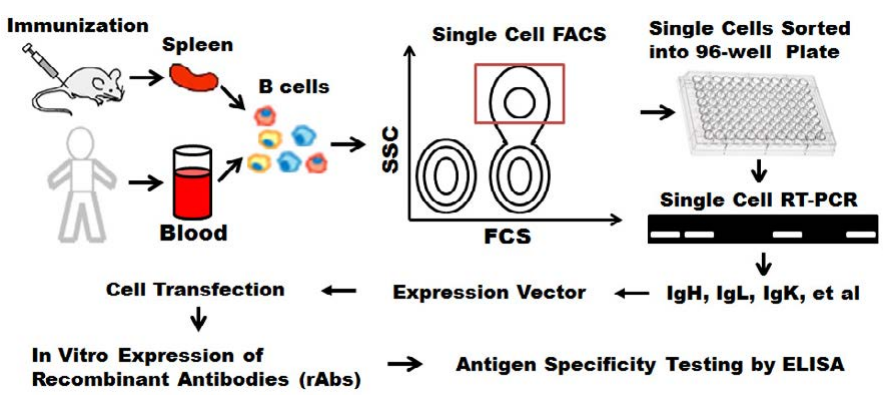

Figure 2. Single cell $\mathrm{mAb}$ cloning using FACS. Single cell sorted using FACS.IgG genes are amplified using single cell RT-PCR, transfected into $293 \mathrm{~T}$ cells with appropriate expression vector for recombinant $\mathrm{mAbs}$. 


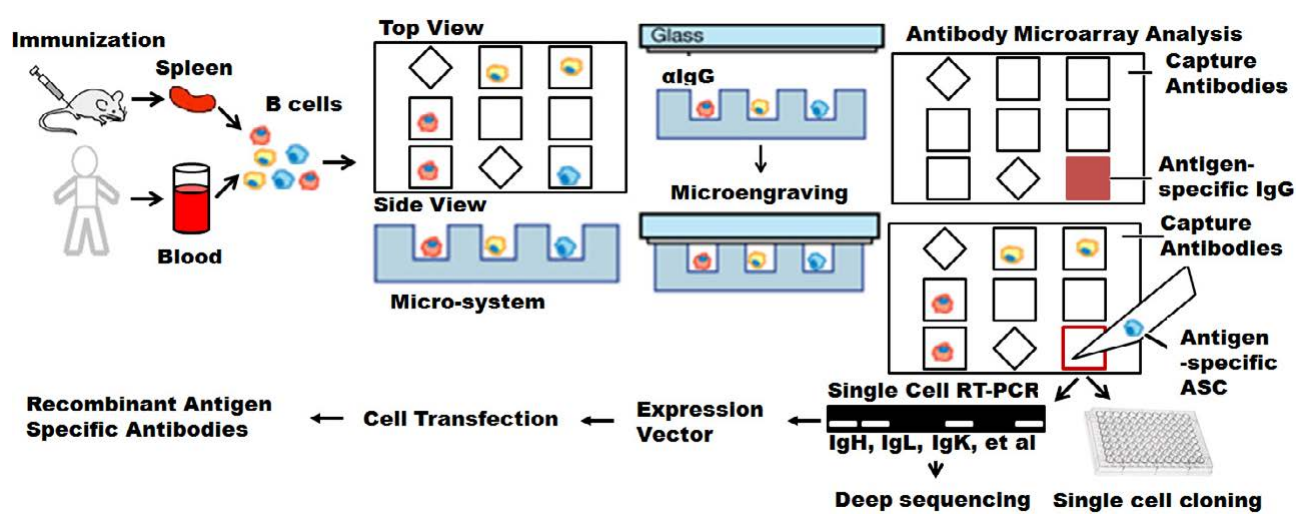

Figure 3. Microsystem enabled single cell monoclonal antibody cloning. Antigens-specific antibody secreting cells (ASC) are identified based on antigen-specific IgG secretion using either microengraving or on-ship immunoassay. Identified single cells can be directly used for single cell cloning. IgG genes isolated from these single cells can be amplified with single cell RTPCR for either deep sequencing or in in vitro recombinant $\mathrm{mAb}$ production.

performed in a random way, therefore this approach is far less efficient than screening method based on antigen-specific secretions.

\section{Microsystem enabled single cell monoclonal antibody (MAb) cloning for Ab immunotherapy of HIV infection}

The time required per assay of antibody secretion using ELISA, as well as the small numbers of cells screened per 96 or 384-plate, limit the overall efficiency of the process, both practically and economically. Microsystem provides dense arrays of microwells with subnanoliter volumes to compartmentalize $10^{4}-10^{6}$ cells for single cell assay [71,72]. Therefore, cell-based microarray [73] and microengraving techniques [74,75] can overcome above limitations to isolate, rapid screen and detect single cells secreting antibodies with the desired reactivity from a large numbers of individual cells. These techniques allow both the high throughput processing, retrieval and cloning of single cells with specificities of interest.

A microarray enabled assay that are defined as immunospot array assay on a chip (ISAAC) enable rapid and efficient manipulation of live single cells to isolate antigen-specific Ab-secreting cells from human peripheral blood. As shown in Figure 3, the chip surface is coated with capture Abs, and the Abs secreted by the Ab-secreting cells are then trapped on the surface around the cells. The binding between capture Abs and targets is detected using fluorescently labeled secondary detection Abs. As a result, the formation of distinct fluorescent spots can be easily distinguished from nonspecific signals [73]. The mechanism of ISAAC is based on ELISPOT.

Strategies that use microengraving technique [74-81] are based on the same principles as ELISA. Microengraving technique uses an engineered micro-tool that is fabricated by a soft lithographic method which modify the biocompatible polymer polydimethylsiloxane (PDMS). Microengraving technique uses the microfabricated array of subnanoliter wells to isolate individual cells spatially and print protein microarrays, where each spot on the array contains the proteins secreted by a single cell [74]. Unique IDs for each micro-well make it possible to position and track individual cells. The array is typically composed of 84,672 microwells, each with dimensions of $50 \mu \mathrm{m}$ length, width, and depth arranged over an area of 1 " $\times 3$ " on a polymeric stamp. Each well holds a volume of approximately $125 \mathrm{pL}$.

The microengraving technique was originally developed to generate microarrays comprising the secreted products of single cells. This method enabled a rapid and high-throughput system for screening of hybridoma cells producing antigen-specific Abs, and subsequent recovery and clonal expansion of single hybridoma cells of interest [75]. Microengraving technique was applied to collect multiparametric datasets that describe the specificity, isotype and apparent affinity of the Abs secreted from many individual primary B cells [76]. Microengraving technique was used to reveal isotype-specific autoreative B cells in Sjogren's syndrome [77]. This technique was applied to detect and isolate auto-reactive human Abs from primary $B$ cells and obtain comprehensive $\mathrm{Ab}$ immune profiles of $\mathrm{B}$ cells isolated from HIV patients [78].

Ig gene cloning is a time consuming process. Both high-throughput methods of ISSAC and microengraving provide compelling advantages for the early and rapid identification of cells secreting antigen-specific antibodies with high affinities and also enable the screening of multiple different clones with distinct specificities in parallel. The advantages provided with microsystem will allow us to single cell cloning HIV vaccine antigen-specific mAb for Ab therapy of HIV infection [79]. Isolated HIV vaccine antigen-specific $B$ cells will also provide nature $\mathrm{V}_{\mathrm{H}}$ and $\mathrm{V}_{\mathrm{L}}$ pairs for subsequent deep sequencing [80-89]. These studies, illustrated in Figure 3 will allow us to functionally characterize HIV vaccine antigen-specific Abs, and to understand the evolution of broad neutralization Abs during the vaccination and maturation process. These methods can also be applied to characterize and sequence HIV vaccine antigen-specific B cells at different anatomical sites, such as blood, bone marrow, mucosal, etc. to reveal the insights of adaptive immune responses in response to HIV infection or vaccines. Meanwhile, the mutiplxed methods can also integrated into the singlecell analytical system to reveal the cell-cell heterogeneities [90-93].

\section{References}

1. Ecker DM, Jones SD, Levine HL (2015) The therapeutic monoclonal antibody market. MAbs 7: 9-14. [Crossref]

2. (2014) Bioprocess Technology Consultants [Internet]. Woburn (MA): Bioprocess Technology Consultants, Inc. bioTRAK_database; 2014 [cited 2014 September 14]; [about 2 screens]. Available from: http://www. bptc.com/pipeline-databases.php

3. (2013) Pharmaceutical Research and Manufacturers of America. Medicines in development: Biologics 2013 Report [Internet]. Washington, DC: Pharmaceutical Research and Manufacturers of America; 2013 Mar [cited 2014 September 14]. 87 p. Available from: http://www. phrma.org/sites/default/files/pdf/biologics2013.pdf

4. (1939)Drugs@FDA[Internet]. Silver Spring (MD): U.S. Food and Drug Administration, Center for Drug Evaluation and Research. 1939- [cited 2014 September 14]. Available from: http://www.accessdata.fda.gov/ scripts/cder/drugsatfda/index.cfm

5. (1995) European public assessment reports, human medicines [Internet]. London: The European Medicines Agency. 1995 [cited 2014 September 14]. Available from: 
http://www.ema.europa.eu/ema/index.jsp?curl=pages/medicines/ landing/epar_search. jsp\&mid=WC0b01ac058001d124

6. (2013) United Nations Development Programme. Human development report 2013: The rise of the South:Human progress in a diverse world [Internet]. NY(NY): United Nations Development Programme; c2013 [cited 2014 September 14]. 216 p. Available from: http://hdr.undp.org/sites/default/files/reports/14/hdr2013_en_complete.pdf

7. Köhler G, Milstein C (1975) Continuous cultures of fused cells secreting antibody of predefined specificity. Nature 256: 495-497. [Crossref]

8. Fuller SA, Takahashi M, Hurrell JGR (2003) Current Protocols in Molecular Biology. John Wiley \& Sons Inc., New York, USA 11.8.1-11.8.2.

9. Yokoyama WM (1995) Current Protocols in Immunology. John Wiley \& Sons Inc., New York, USA 2.5.1-2.5.17.

10. Greenfield EA (2014) Antibodies A Laboratory Manual. (Edn. $2^{\text {nd }}$ ) Cold Spring Harbor Laboratory Press, USA.

11. Davis JM, Pennington JE, Kubler AM, Conscience JF (1982) A simple, single-step technique for selecting and cloning hybridomas for the production of monoclonal antibodies. J Immunol Methods 50: 161-171. [Crossref]

12. Rueda AZ, Coll JM (1988) Cloning of myelomas and hybridomas in fibrin clots. $J$ Immunol Methods 114: 213-217. [Crossref]

13. Herzenberg LA, Parks D, Sahaf B, Perez O, Roederer M, et al. (2002) The history and future of the fluorescence activated cell sorter and flow cytometry: a view from Stanford. Clin Chem 48: 1819-1827. [Crossref]

14. Carroll S, Al-Rubeai M (2004) The selection of high-producing cell lines using flow cytometry and cell sorting. Expert Opin Biol Ther 4: 1821-1829. [Crossref]

15. Lagerkvist AC, Furebring C, Borrebaeck CA (1995) Single, antigen-specific B cells used to generate Fab fragments using CD40-mediated amplification or direct PCR cloning. Biotechniques 18: 862-869. [Crossref]

16. Battye FL, Light A, Tarlinton DM (2000) Single cell sorting and cloning. J Immunol Methods 243: 25-32. [Crossref]

17. Herzenberg LA, Parks D, Sahaf B, Perez O, Roederer M, et al. (2002) The history and future of the fluorescence activated cell sorter and flow cytometry: a view from Stanford. Clin Chem 48: 1819-1827. [Crossref]

18. Scheid JF, Mouquet H, Feldhahn N, Walker BD, Pereyra F, et al. (2009) A method for identification of HIV gp140 binding memory B cells in human blood. $J$ Immunol Methods 343: 65-67. [Crossref]

19. Smith K, Garman L, Wrammert J, Zheng NY, Capra JD, et al. (2009) Rapid generation of fully human monoclonal antibodies specific to a vaccinating antigen. Nat Protoc 4: 372-384. [Crossref]

20. Glassman PM, Balthasar JP1 (2014) Mechanistic considerations for the use of monoclonal antibodies for cancer therapy. Cancer Biol Med 11: 20-33. [Crossref]

21. Nimmerjahn F, Ravetch JV (2010) Antibody-mediated modulation of immune responses. Immunol Rev 236: 265-275. [Crossref]

22. Scott LJ, Lamb HM (1999) Palivizumab. Drugs 58: 305-311. [Crossref]

23. Mascola JR, Lewis MG, Stiegler G, Harris D, VanCott TC, et al. (1999) Protection of Macaques against pathogenic simian/human immunodeficiency virus $89.6 \mathrm{PD}$ by passive transfer of neutralizing antibodies. $J$ Virol 73: 4009-4018. [Crossref]

24. Mascola JR, Stiegler G, VanCott TC, Katinger H, Carpenter CB, et al. (2000) Protection of macaques against vaginal transmission of a pathogenic HIV-1/SIV chimeric virus by passive infusion of neutralizing antibodies. Nat Med 6: 207-210. [Crossref]

25. Baba TW, Liska V, Hofmann-Lehmann R, Vlasak J, Xu W, et al. (2000) Human neutralizing monoclonal antibodies of the IgG1 subtype protect against mucosal simian-human immunodeficiency virus infection. Nat Med 6: 200-206. [Crossref]

26. Parren PW, Gauduin MC, Koup RA, Poignard P, Sattentau QJ, et al. (1997) Relevance of the antibody response against human immunodeficiency virus type 1 envelope to vaccine design. Immunol Lett 57: 105-112. [Crossref]

27. Hessell AJ, Poignard P, Hunter M, Hangartner L, Tehrani DM, et al. (2009) Effective, low-titer antibody protection against low-dose repeated mucosal SHIV challenge in macaques. Nat Med 15: 951-954. [Crossref]

28. Hessell AJ, Rakasz EG, Poignard P, Hangartner L, Landucci G, et al. (2009) Broadly neutralizing human anti-HIV antibody 2 G12 is effective in protection against mucosa SHIV challenge even at low serum neutralizing titers. PLoS Pathog 5: e1000433. [Crossref]
29. Hessell AJ, Rakasz EG, Tehrani DM, Huber M, Weisgrau KL, et al. (2010) Broadly neutralizing monoclonal antibodies $2 \mathrm{~F} 5$ and $4 \mathrm{E} 10$ directed against the human immunodeficiency virus type 1 gp41 membrane-proximal external region protect against mucosal challenge by simian-human immunodeficiency virus SHIVBa-L. $J$ Virol 84: 1302-1313. [Crossref]

30. Doria-Rose NA, Klein RM, Manion MM, O'Dell S, Phogat A, et al. (2009) Frequency and phenotype of human immunodeficiency virus envelope-specific B cells from patients with broadly cross-neutralizing antibodies. J Virol 83: 188-199. [Crossref]

31. Mikell I, Sather DN, Kalams SA, Altfeld M, Alter G, et al. (2011) Characteristics of the earliest cross-neutralizing antibody response to HIV-1. PLoS Pathog 7: e1001251. [Crossref]

32. Gray ES, Madiga MC, Hermanus T, Moore PL, Wibmer CK, et al. (2011) The neutralization breadth of HIV-1 develops incrementally over four years and is associated with $\mathrm{CD} 4+\mathrm{T}$ cell decline and high viral load during acute infection. $J$ Virol 85: 4828-4840. [Crossref]

33. Sather DN, Armann J, Ching LK, Mavrantoni A, Sellhorn G, et al. (2009) Factors associated with the development of cross-reactive neutralizing antibodies during human immunodeficiency virus type 1 infection. $J$ Virol 83: 757-769. [Crossref]

34. Simek MD, Rida W, Priddy FH, Pung P, Carrow E, et al. (2009) Human immunodeficiency virus type 1 elite neutralizers: individuals with broad and potent neutralizing activity identified by using a high-throughput neutralization assay together with an analytical selection algorithm. $J$ Virol 83: 7337-7348. [Crossref]

35. Klein F, Mouquet H, Dosenovic P, Scheid JF, Scharf L, et al. (2013) Antibodies in HIV1 vaccine development and therapy. Science 341: 1199-1204. [Crossref]

36. Horwitz JA, Halper-Stromberg A, Mouquet H, Gitlin AD, Tretiakova A, et al. (2013) HIV-1 suppression and durable control by combining single broadly neutralizing antibodies and antiretroviral drugs in humanized mice. Proc Natl Acad Sci U S A 110 : 16538-16543. [Crossref]

37. Barouch DH, Whitney JB, Moldt B, Klein F, Oliveira TY, et al. (2013) Therapeutic efficacy of potent neutralizing HIV-1-specific monoclonal antibodies in SHIV-infected rhesus monkeys. Nature 503: 224-228. [Crossref]

38. Shingai M, Nishimura Y, Klein F, Mouquet H, Donau OK, et al. (2013) Antibodymediated immunotherapy of macaques chronically infected with SHIV suppresses viraemia. Nature 503: 277-280. [Crossref]

39. Caskey M, Klein F, Lorenzi JC, Seaman MS, West AP Jr, et al. (2015) Viraemia suppressed in HIV-1-infected humans by broadly neutralizing antibody 3BNC117. Nature 522: 487-491. [Crossref]

40. Stähli C, Staehelin T, Miggiano V, Schmidt J, Häring P (1980) High frequencies of antigen-specific hybridomas: dependence on immunization parameters and prediction by spleen cell analysis. J Immunol Methods 32: 297-304. [Crossref]

41. Aman P, Ehlin-Henriksson B, Klein G (1984) Epstein-Barr virus susceptibility of normal human B lymphocyte populations. J Exp Med 159: 208-220. [Crossref]

42. Redmond MJ, Leyritz-Wills M, Winger L, Scraba DG (1986) The selection and characterization of human monoclonal antibodies to human cytomegalovirus. J Virol Methods 14: 9-24. [Crossref]

43. James K, Bell GT (1987) Human monoclonal antibody production. Current status and future prospects. J Immunol Methods 100: 5-40. [Crossref]

44. Borrebaeck CA, Danielsson L, Möller SA (1988) Human monoclonal antibodies produced by primary in vitro immunization of peripheral blood lymphocytes. Proc Nat Acad Sci U S A 85: 3995-3999. [Crossref]

45. Crain MJ, Sanders SK, Butler JL, Cooper MD (1989) Epstein-Barr virus preferentially induces proliferation of primed B cells. J Immunol 143: 1543-1548. [Crossref]

46. Wardemann H, Yurasov S, Schaefer A, Young JW, Meffre E, et al. (2003) Predominant autoantibody production by early human B cell precursors. Science 301: 1374-1377. [Crossref]

47. Walker LM, Phogat SK, Chan-Hui PY, Wagner D, Phung P, et al. (2009) Broad and potent neutralizing antibodies from an African donor reveal a new HIV-1 vaccine target. Science 326: 285-289. [Crossref]

48. Walker LM, Huber M, Doores KJ, Falkowska E, Pejchal R, et al. (2011) Broad neutralization coverage of HIV by multiple highly potent antibodies. Nature 477: 466470. [Crossref]

49. Bonsignori M, Montefiori DC, Wu X, Chen X, Hwang KK, et al. (2012) Two distinct broadly neutralizing antibody specificities of different clonal lineages in a single HIV1-infected donor: implications for vaccine design. $J$ Virol 86: 4688-4692. [Crossref] 
50. Julien JP, Sok D, Khayat R, Lee JH, Doores KJ, et al. (2013) Broadly neutralizing antibody PGT121 allosterically modulates CD4 binding via recognition of the HIV-1 gp120 V3 base and multiple surrounding glycans. PLoS Pathog 9: e1003342. [Crossref]

51. Scheid JF, Mouquet H, Feldhahn N, Seaman MS, Velinzon K, et al. (2009) Broad diversity of neutralizing antibodies isolated from memory B cells in HIV-infected individuals. Nature 458: 636-640. [Crossref]

52. Scheid JF, Mouquet H, Feldhahn N, Walker BD, Pereyra F, et al. (2009) A method for identification of HIV gp140 binding memory B cells in human blood. J Immunol Methods 343: 65-67. [Crossref]

53. Dey B, Svehla K, Xu L, Wycuff D, Zhou T, et al. (2009) Structure-based stabilization of HIV-1 gp120 enhances humoral immune responses to the induced co-receptor binding site. PLoS Pathog 5: e1000445. [Crossref]

54. Zhou T, Xu L, Dey B, Hessell AJ, Van Ryk D, et al. (2007) Structural definition of a conserved neutralization epitope on HIV-1 gp120. Nature 445: 732-737. [Crossref]

55. Klein F, Gaebler C, Mouquet H, Sather DN, Lehmann C, et al. (2012) Broad neutralization by a combination of antibodies recognizing the CD4 binding site and a new conformational epitope on the HIV-1 envelope protein. J Exp Med 209: 14691479. [Crossref]

56. Tiller T, Meffre E, Yurasov S, Tsuiji M, Nussenzweig MC, et al. (2008) Efficient generation of monoclonal antibodies from single human B cells by single cell RT-PCR and expression vector cloning. J Immunol Methods 329: 112-124. [Crossref]

57. Scheid JF, Mouquet H, Ueberheide B, Diskin R, Klein F, et al. (2011) Sequence and structural convergence of broad and potent HIV antibodies that mimic CD4 binding. Science 333: 1633-1637. [Crossref]

58. Mouquet H, Scharf L, Euler Z, Liu Y, Eden C, et al. (2012) Complex-type N-glycan recognition by potent broadly neutralizing HIV antibodies. Proc Natl Acad Sci U S A 109: E3268-3277. [Crossref]

59. Burton DR, Poignard P, Stanfield RL, Wilson IA (2012) Broadly neutralizing antibodies present new prospects to counter highly antigenically diverse viruses. Science 337: 183-186. [Crossref]

60. Corti D, Langedijk JP, Hinz A, Seaman MS, Vanzetta F, et al. (2010) Analysis of memory $\mathrm{B}$ cell responses and isolation of novel monoclonal antibodies with neutralizing breadth from HIV-1-infected individuals. PLoS One 5: e8805. [Crossref]

61. Haynes BF, Kelsoe G, Harrison SC, Kepler TB (2012) B-cell-lineage immunogen design in vaccine development with HIV-1 as a case study. Nat Biotechnol 30: 423433. [Crossref]

62. Klein F, Gaebler C, Mouquet H, Sather DN, Lehmann C, et al. (2012) Broad neutralization by a combination of antibodies recognizing the CD4 binding site and a new conformational epitope on the HIV-1 envelope protein. J Exp Med 209: 14691479. [Crossref]

63. Kong L, Sattentau QJ (2012) Antigenicity and Immunogenicity in HIV-1 AntibodyBased Vaccine Design. J AIDS Clin Res S8: 3. [Crossref]

64. Moir S, Malaspina A, Fauci AS (2011) Prospects for an HIV vaccine: leading B cells down the right path. Nat Struct Mol Biol 18: 1317-1321. [Crossref]

65. Overbaugh J, Morris L (2012) The Antibody Response against HIV-1. Cold Spring Harb Perspect Med 2: a007039. [Crossref]

66. Wu X, Yang ZY, Li Y, Hogerkorp CM, Schief WR, et al. (2010) Rational design of envelope identifies broadly neutralizing human monoclonal antibodies to HIV-1. Science 329: 856-861. [Crossref]

67. Wu X, Zhou T, Zhu J, Zhang B, Georgiev I, et al. (2011) Focused evolution of HIV-1 neutralizing antibodies revealed by structures and deep sequencing. Science 333: 15931602. [Crossref]

68. Liao HX, Levesque MC, Nagel A, Dixon A, Zhang R, et al. (2009) High-throughput isolation of immunoglobulin genes from single human B cells and expression as monoclonal antibodies. J Virol Methods 158: 171-179. [Crossref]

69. Silveira EL, Kasturi SP, Kovalenkov Y, Rasheed AU, Yeiser P, et al. (2015) Vaccineinduced plasmablast responses in rhesus macaques: phenotypic characterization and a source for generating antigen-specific monoclonal antibodies. J Immunol Methods 416: 69-83. [Crossref]

70. Meng W, Li L, Xiong W, Fan X, Deng H, et al. (2015) Efficient generation of monoclonal antibodies from single rhesus macaque antibody secreting cells. MAbs 7 : 707-718. [Crossref]

71. Whitesides GM (2006) The origins and the future of microfluidics. Nature 442: 368373. [Crossref]
72. Sackmann EK, Fulton AL2, Beebe DJ3 (2014) The present and future role of microfluidics in biomedical research. Nature 507: 181-189. [Crossref]

73. Jin A, Ozawa T, Tajiri K, Obata T, Kondo S, et al. (2009) A rapid and efficient singlecell manipulation method for screening antigen-specific antibody-secreting cells from human peripheral blood. Nat Med 15: 1088-1092. [Crossref]

74. Song Q, Han Q, Bradshaw EM, Kent SC, Raddassi K, et al. (2010) On-chip activation and subsequent detection of individual antigen-specific T cells. Anal Chem 82: 473477. [Crossref]

75. Love JC, Ronan JL, Grotenbreg GM, van der Veen AG, Ploegh HL (2006) A microengraving method for rapid selection of single cells producing antigen-specific antibodies. Nat Biotechnol 24: 703-707. [Crossref]

76. Ogunniyi AO, Story CM, Papa E, Guillen E, Love JC (2009) Screening individua hybridomas by microengraving to discover monoclonal antibodies. Nat Protoc 4: 767-782. [Crossref]

77. Story CM, Papa E, Hu CC, Ronan JL, Herlihy K, et al. (2008) Profiling antibody responses by multiparametric analysis of primary B cells. Proc Natl Acad Sci U S A 105: 17902-17907. [Crossref]

78. Nguyen CQ, Ogunniyi AO, Karabiyik A, Love JC (2013) Single-cell analysis reveals isotype-specific autoreactive B cell repertoires in Sjögren's syndrome. PLoS One 8: e58127. [Crossref]

79. Ogunniyi AO, Thomas BA, Politano TJ, Varadarajan N, Landais E, et al. (2014) Profiling human antibody responses by integrated single-cell analysis. Vaccine 32 : 2866-2873. [Crossref]

80. Weiss RA (2014) Immunotherapy for HIV Infection. $N$ Engl J Med 370: 379-380 [Crossref]

81. Tsioris K, Gupta NT, Ogunniyi AO, Zimnisky RM, Qian F, et al. (2015) Neutralizing antibodies against West Nile virus identified directly from human B cells by single-cell analysis and next generation sequencing. Integr Biol (Camb) 7: 1587-1597. [Crossref]

82. Georgiou G, Ippolito GC, Beausang J, Busse CE, Wardemann H, et al. (2014) The promise and challenge of high-throughput sequencing of the antibody repertoire. Nat Biotechnol 32: 158-168. [Crossref]

83. Zhu J, Ofek G, Yang Y, Zhang B, Louder MK, et al. (2013) Mining the antibodyome for HIV-1-neutralizing antibodies with next-generation sequencing and phylogenetic pairing of heavy/light chains. Proc Natl Acad Sci U S A 110: 6470-6475. [Crossref]

84. Zhu J, Wu X, Zhang B, McKee K, O’Dell S, et al. (2013) De novo identification of VRC01 class HIV-1-neutralizing antibodies by next-generation sequencing of B-cell transcripts. Proc Natl Acad Sci U S A 110: E4088-4097. [Crossref]

85. Lavinder JJ, Horton AP, Georgiou G, Ippolito GC (2015) Next-generation sequencing and protein mass spectrometry for the comprehensive analysis of human cellular and serum antibody repertoires. Curr Opin Chem Biol 24: 112-120. [Crossref]

86. He L, Sok D, Azadnia P, Hsueh J, Landais E, et al. (2014) Toward a more accurate view of human B-cell repertoire by next-generation sequencing, unbiased repertoire capture and single-molecule barcoding. Scientific Reports 4: 6778.

87. Dai K, He L, Khan SN, O'Dell S, McKee K, et al. (2015) Rhesus Macaque B-Cell Responses to an HIV-1 Trimer Vaccine Revealed by Unbiased Longitudinal Repertoire Analysis. MBio 6: e01375-01315. [Crossref]

88. Reddy ST, Ge X, Miklos AE, Hughes RA, Kang SH, et al. (2010) Monoclonal antibodies isolated without screening by analyzing the variable-gene repertoire of plasma cells. Nat Biotechnol 28: 965-969. [Crossref]

89. Georgiou G, Ippolito GC, Beausang J, Busse CE, Wardemann H, et al. (2014) The promise and challenge of high-throughput sequencing of the antibody repertoire. Nat Biotechnol 32: 158-168. [Crossref]

90. Mathonet P, Ullman CG (2013) The application of next generation sequencing to the understanding of antibody repertoires. Front Immunol 4: 265. [Crossref]

91. Chai J, Song Q (2015) Multiple-protein detections of single-cells reveal cell-cell heterogeneity in human cells. IEEE Trans Biomed Eng 62: 30-38. [Crossref]

92. Chai J, Song Q (2014) Quantitative and multiplexed study of endothelial cell inflammation. Cell Biochem Biophys 70: 1783-1790. [Crossref]

93. Chai JW, Song Q (2012) Multi-spectral concurrent detection of multiple proteins. Nanolife 2: 1250013

Copyright: (C2016 Song Q. This is an open-access article distributed under the terms of the Creative Commons Attribution License, which permits unrestricted use, distribution, and reproduction in any medium, provided the original author and source are credited. 